\title{
ADAPTATION STRATEGY OF MOSQUE ARCHITECTURE IN THE MINORITY NEIGHBORHOOD \\ Case Studies: Mosques in Denpasar City and Badung Regency, Province of Bali.
}

\author{
Andika Saputra \\ Alumnus of Master of Science Program, Post-Graduate \\ Architecture, Faculty of Engineering, Universitas Gadjah \\ Mada, Yogyakarta \\ e-mail: andikasapoetra87@yahoo.com
}

Muhammad Rochis

Alumnus of Bachelor Architecture Program, Faculty of Engineering Warmadew University, Denpasar City, Bali e-mail: muhammadrochis90@yahoo.com

Received: May $31^{\text {st }} 2014$; Accepted: September $3^{\text {rd }} 2014$; Available Online: December $15^{\text {th }} 2014$

\begin{abstract}
Mosques for Moslems who live in the middle of minority neighborhood in Province of Bali do not only function as a signifier for the presence of a Moslem community, but also have a central role because mosque is the only gathering place for fellow Moslems. In the present, Moslems in the province of Bali is facing various challenges that cause adaptation strategies of mosque architecture for the existence of mosque in the neighborhood can be accepted by society from other faith. This preliminary study aim to know the adaptation strategies of mosque architecture undertaken Moslems in the province of Bali along with the factor that drive adaptation. Study conducted using qualitative-inductive method. Locus of study in the Denpasar City and Badung Regency where is the center of activity and concentration of Moslems in the province of Bali in a different background of neighborhood. Object of study used a large mosque that are the central of Moslems activity. The finding of this study showed that there are three types of mosque architecture adaptation strategies undertaken by Moslems in the Province of Bali are (1) external factor is responded by applying dominate elements of Balinese style architecture, (2) internal factor is awareness to apply elements of Balinese style architecture to show identity as a Moslems who appreciate local value, and (3) internal factor to apply the characteristic architectural style of the Middle East mosque is considered ideal to represent identity as Moslems.
\end{abstract}

Keywords: adaptation strategies, mosque architecture, minority neighborhood

\begin{abstract}
Abstrak
Masjid bagi umat Islam di Provinsi Bali yang hidup di tengah lingkungan minoritas tidak saja berfungsi simbolis sebagai penanda keberadaan komunitas Islam namun juga memiliki peran sentral dikarenakan merupakan satusatunya tempat berkumpul bagi sesama umat Islam. Di masa kekinian, umat Islam di Provinsi Bali tengah menghadapi berbagai tantangan yang menyebabkan dilakukannya strategi adaptasi arsitektur masjid agar keberadaan masjid di lingkungannya dapat diterima oleh masyarakat luas dari berbagai agama. Kajian awal ini bertujuan untuk mengetahui strategi adaptasi arsitektur masjid yang dilakukan oleh umat Islam di Provinsi Bali beserta dengan faktor-faktor yang mendorong dilakukannya adaptasi. Kajian dilakukan dengan menggunakan metode kualitatif induktif. Lokus kajian berada di Kota Denpasar dan Kabupaten badung yang merupakan pusat kegiatan dan konsentrasi kehidupan umat Islam di Provinsi Bali dengan latar belakang lingkungan yang berbeda. Obyek kajian yang digunakan merupakan masjid-masjid besar yang merupakan pusat kegiatan umat Islam. Hasil kajian menunjukkan bahwa ditemukan tiga tipe strategi adaptasi arsitektur masjid yang dilakukan oleh umat Islam di Provinsi Bali yaitu (1) faktor eksternal yang ditanggapi dengan dominan menerapkan unsur arsitektur gaya Bali; (2) kesadaran dari dalam diri menerapkan unsur arsitektur gaya Bali untuk menunjukkan identitasnya sebagai komunitas Moslem yang menghargai nilai-nilai lokal; dan (3) Faktor internal untuk menerapkan ciri khas arsitektur masjid gaya Timur Tengah yang dianggap ideal merepresentasikan identitasnya sebagai umat Islam.
\end{abstract}

Kata kunci: strategi adaptasi, arsitektur masjid, lingkungan minoritas

\section{Introduction}

The number of Moslems in the province of Bali in 2010[1] are 323.853 people with second position after Hindus who are more than 2.7 million people. Total population in province of Bali reached 3.2 million people. Every year the number of Moslem in the province of Bali increases which majority by the immigrant from Java caused economic motive. In the present, concentration of Moslems life in Bali took place in Denpasar City as a capital of the province of 
Bali and Badung regency as a major tourist destination in the province of Bali where the two districts is a center of economic activity in the province of Bali.

Living in the minority neighborhood does not make Moslems in the province of Bali not show the symbol of Islam. One of the symbol of Islam is mosque, as the statement of Sheikh Khairuddin Wanili [2], "Mosque is symbol of Islam. If there is no adzan, no shalat, and no shalat jama'ah, then there is no Islam and Moslems in that area ".

Sheikh Yasin Huri Husain [3] stated that a mosque has an important role throughout the history of Moslems which get the main priority and the deep concern of the Moslem leaders and all of the Moslem community. Therefore Moslems culture born from mosque which depend on the function of mosque[4].

Mosque for Moslems in the province of Bali not only function as a symbolic of the presence of Moslem community in that area, but also have a central role as a center place for Moslems activity, considering living in the minority neighborhood making mosque is the only gathering place for fellow Moslems.

At the present, Moslems in the province of Bali facing various challenges in various fields of life to be able to adaptation with the culture of majority society. Especially after the Bali bombing in 2002 which lead to suspicion excessive attitude against Moslems in the province of Bali in generaly, and in Denpasar city and Badung regency in particulary where the location of the Bali bombing.

Hamdan Basyar based on his research in the province of Bali in 2010 [5] revealed, although on the surface looks harmonious relationship, but Moslems who live in the province of Bali are under pressured by Hindus domination in religious life, social, economic, and cultural. One of which impacts is difficulty in obtaining permits to establishment of mosque and local regulation based on Hindu values.

Living in the minority neighborhood with a variety of contemporary challenges to be faced, encourage Moslems in province of Bali to maximize the function of mosque to represent a aspiration and activities of Moslems. On the one hand, Moslems want to show their religious identity through the mosque architecture is considered ideal, but on the other hand there are demand from local goverment to apply the characteristic of Balinese style architecture which has been approved in regulation as well as demand to maintain religious harmony with other believer because of feared by showing Islamic identity can trigger horizontal conflicts.

This study is a preliminary study that aims to know the adaptation strategies of mosque architecture undertaken Moslems in the province of Bali along with the factors that drive adaptation. The result of this study are expected to provide benefits in two aspect. First, for the practice of architecture, the results of this study can be a design guideline of mosque architecture in the province of Bali. Second, for Moslems, the results of this study can provide information about adaptation strategies in the field of mosque architecture in an effort to retain the existence of mosque which are symbol of Islam in the minority neighborhood.

By knowing the adaptation strategies undertaken by Moslems in the Provice of Bali, it can describe an identity of Moslems in the province of Bali, as stated by Prof. Syaom Barliana [6] that the mosque is a representation of Moslems who give birth and prosper, which come from all the capabilities of that people.

\section{Research Method}

This preliminary study applies inductivequalitative method, with the selection of locus and object of study purposively. Chosen locus of study in Denpasar city and Badung regency because these two districts is the center of Moslems' life and activity in the province of Bali with a different background neighborhood in which Denpasar city is rigorous to application of local cultural values as the capital of Province of Bali and Badung regency more 'loose' to application of local cultural values as a major tourist destination in the province of Bali with a more heterogeneous society cultural background.

Object of study used is a large mosque in the two districts which is the central of Moslems activity, are al-Qomar Mosque and Sudirman Grand Mosque in Denpasar city and Nurul Huda Mosque and Asasuttaqwa Mosque in Badung regency.

In the future this study will continue to increase the quantity of object of study in another locus of study with a more diverse neighborhood background so will get more comprehensive result about adaptation strategy of mosque architecture undertaken by Moslem in the province of Bali.

Variable used to assess adaptation strategy of mosque architecture in Denpasar city and Badung regency are exterior element of the mosque building is seen from the aspect of form, material, ornament, and color. Variable used are limited because this is a preliminary study and possibly that in the next study do addition a variable to get a more comprehensive result about adaptation strategy of mosque architecture in the province of Bali.

Technique of data collection using observation and semi-structured interview by purposively selection informant with criteria a informant who has authority over the object of study, as follow:

1. Suhaeri, as a chairman of foundation and chairman of ta'mir of al-Qomar Mosque.

2. Tri Sudirman, as a vice chairman of ta'mir of Sudirman Grand Mosque. 
3. H. Abdul Malik, as a chairman of ta'mir of Nurul Huda Mosque.

4. Priyatno Adi, as a senior member of Nurul Huda Mosque.

5. H. Hanafi, as a general secretary of ta'mir of Asasuttaqwa Mosque.

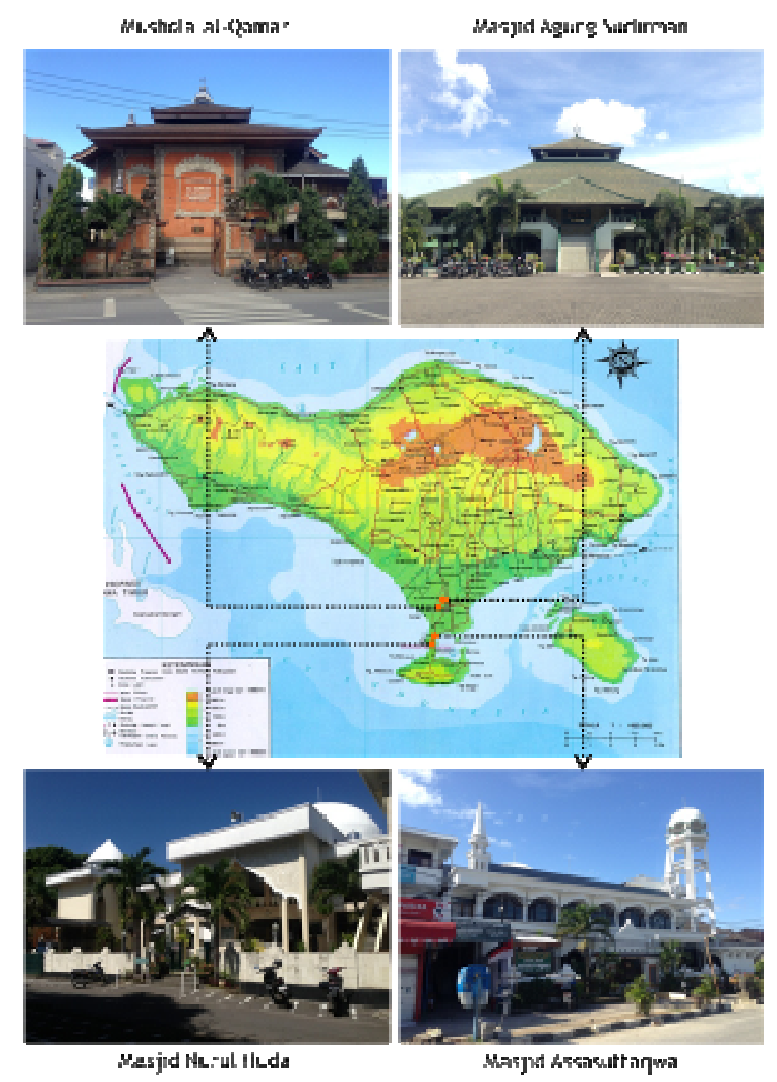

Figure 1. Location map of object of study (Source: survey, 2013)

Non-physical data obtained in this preliminary study has not yet reached saturation level because limitation of time and informant so in the next study collecting data can continous with applying the snowball sampling technique to deepen quality of data while triangulation of data to ensure a data validation.

\section{Profile of Object}

\section{1. al-Qomar Mosque, Denpasar City.}

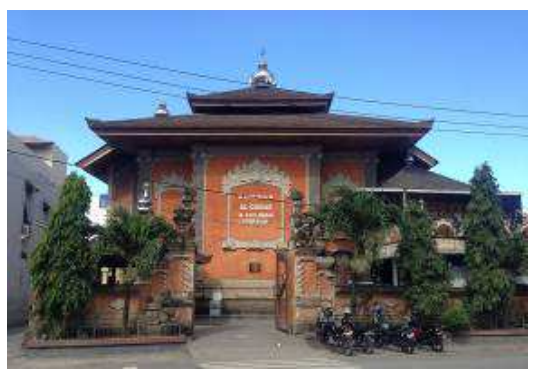

Figure 2. Front elevation of al-Qomar Mosque (Source: survey, 2013)
The object of study is located in Pura Demak Street, subdistrict of West Teuku Umar, district of West Denpasar. Al-Qomar Mosque built in 1980s was initiated by the elders of the local figure. The beginning of al-Qomar Mosque only a very simple building. Over time, al-Qomar Mosque has been renovated twice in 1995 and 2001, so making the current form of mosque building until present with an area $400 \mathrm{~m}^{2}$.

\section{Sudirman Grand Mosque, Denpasar City.}

The object of study is located in Slamet Riyadi Street, District of East Denpasar, in the area of Udayana Military Command. The construction caused of Sudirman Grand Mosque because necessary a worship space for Moslems in the area of Udayana Military Command that are increasingly from year to year.

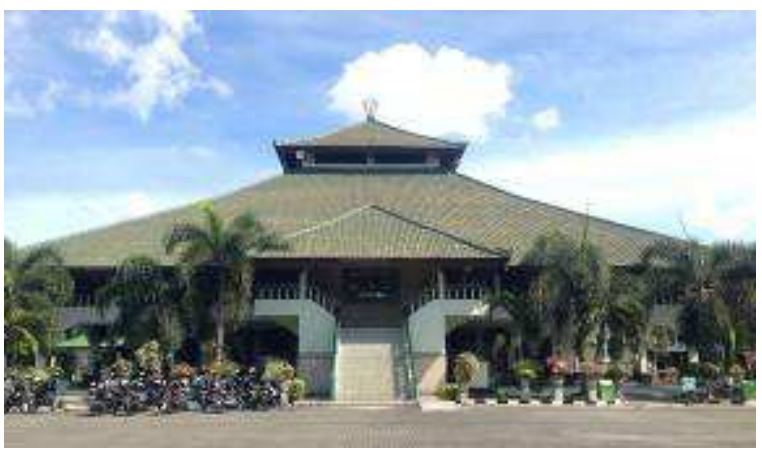

Figure 3. Front elevation of Sudirman Grand Mosque (Source: survey, 2013)

At Ramadan 1972 and 1973, langgar in the area of Udayana Military Command no longer able to accommodate a number of the tarawih prayers so that the congregation forced to pray in office building, court, and warehouse building. Because of that at 1974 it was decided to build a mosque by the idea of Drs. Zainuddin, H. Mat Nur, et al, which is a member of TNI.

Since its constructing, Sudirman Grand Mosque have been renovated several times at 1979 to repair the building which have been damaged, and at 1994 to expand the mosque building and at the same time change the overall form of the mosque building. Renovation was completed at 2000 and making the current form of the mosque building until present with an area $900 \mathrm{~m}^{2}$.

\section{Nurul Huda Mosque, Badung Regency.}

The object of study is located in Sentani Street, District of North Kuta, Badung regency, near with Ngurah Rai airport. Nurul Huda Mosque established on land designated for worship building of Moslems, Hindus, and Christians, therefore Nurul Huda Mosque adjacent with the temple on the east and the church building on the south. 
Nurul Huda Mosque was built at 1970 by the idea of Ir. Hertoto and built by PT. Angkasa Pura 1. At the beginning of construction, the mosque have very simple form with a building area $100 \mathrm{~m}^{2}$. At 2003, Nurul Huda Mosque undergoing renovation and making the current form of the mosque building until present with an area $484 \mathrm{~m}^{2}$.

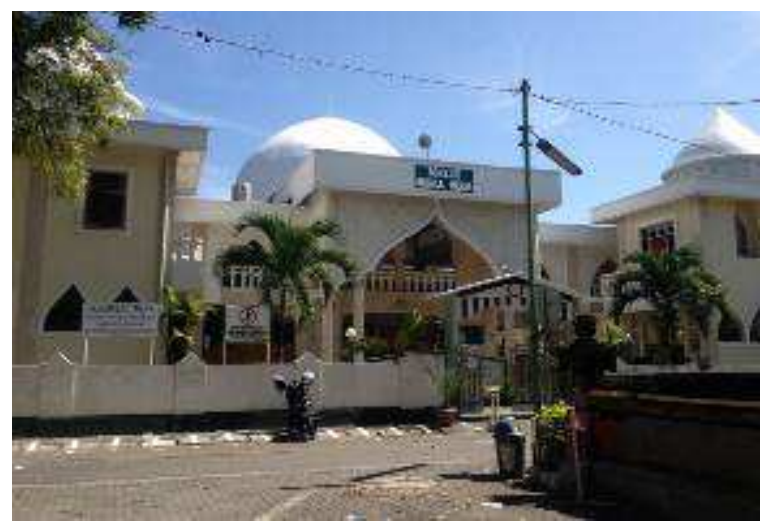

Figure 4. Front elevation of Nurul Huda Mosque (Source: survey, 2013)

\section{Asasuttaqwa Mosque, Badung Regency.}

The object of study is located in Ngurah Rai Street, District of North Kuta, Badung regency. Asasuttaqwa mosque has established since the Dutch colonial era in the land of Puri Pamecutan as remuneration to the aid of Moslems against Dutch colonial.

Since its constructing, Asasuttaqwa mosque have been renovated four times. Last renovation was conducted at early 1990 to become the present form of the mosque building with an area $529 \mathrm{~m}^{2}$. Renovation can be completed within a year and running smoothly due to the strength of the material and non-material support from Moslems as a congregation around the mosque and Moslems as government official.

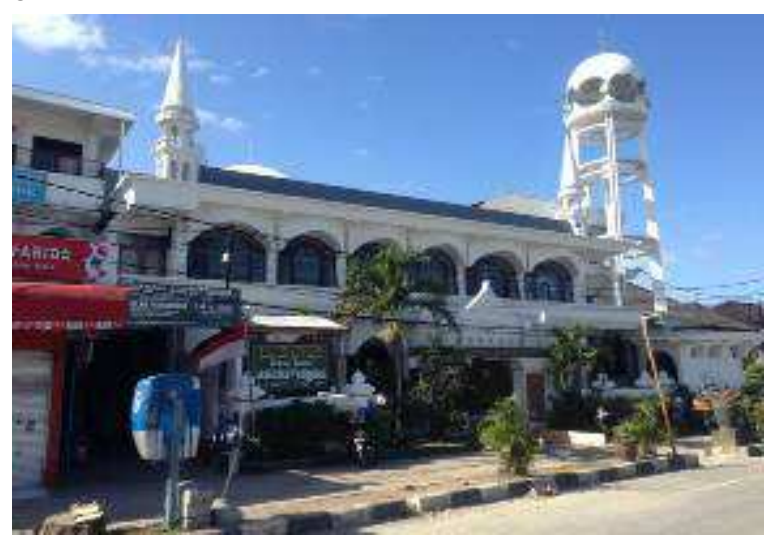

Figure 5. Front elevation of Asasuttaqwa Mosque (Source: survey, 2013)

\section{Analysis}

1. al-Qomar Mosque, Denpasar City.

The last renovation at 2001 changed the overall form of al-Qomar Mosque by applying the typical element of Balinese style architecture. From the aspect of building form, the mosque building have leg-body-head part is identical to the concept of tri angga from Balinese style architecture. The leg part of building is identical with bebaturan element from Balinese style architecture, which sustain massive body part because material characteristic that used.

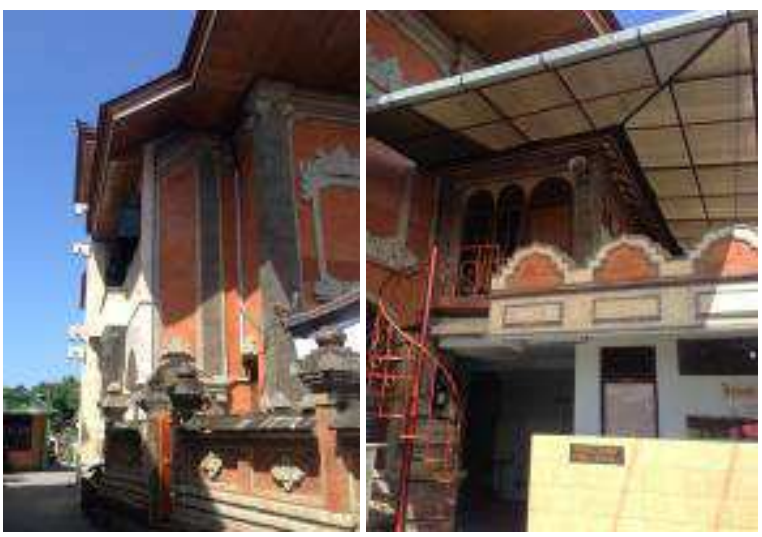

Figure 6. Material and ornament in al-Qomar Mosque (Source: survey, 2013)

The leg and body part of mosque building using brick, sandstone, and temple stone which are the typical Balinese style architecture, making the building of al-Qomar Mosque dominate a red color as well as beige and gray. Al-Qomar Mosque also applying ornament of Balinese style architecture, where at the leg part of building occur pepalihan ornament and in the body part occur pepatran and kekarangan ornament with stylization so it does not reveal real form.

The head part of mosque building applies pyramid roof with the largest roof which two level storey roof and ornament dome on the top covered the main prayer hall. From the material aspect, the head part of mosque building use roof tile material with ikut celedu ornament which typical Balinese style architecture in each edge of the ridge.

Nuance of Balinese style architecture a more condensed by applying candi bentar and paduraksa element with material, color, and ornament as typical Balinese style architectue in the fence. As the body part of the mosque building, the ornament on the fence not to reveal real form.

Factor that the al-Qomar Mosque applying dominate Balinese style architecture because of the government demand at 2001 to comply the regulation relating Balinese architecture values, is no exception for worship places of Moslems. At the beginning, congregation of al-Qomar Mosque rejected that government demand because do not show the ideal mosque by the congregation. 
However, after discussion and persuasive approach the congregation agreed to change the form of alQomar Mosque building by applying element of Balinese style architecture. The decision was taken in consideration is more concerned to the existence of al-Qomar Mosque as worship place and gathering for Moslems than feared in the future tangled legal issue as well as issue of horizontal conflict with other believer.

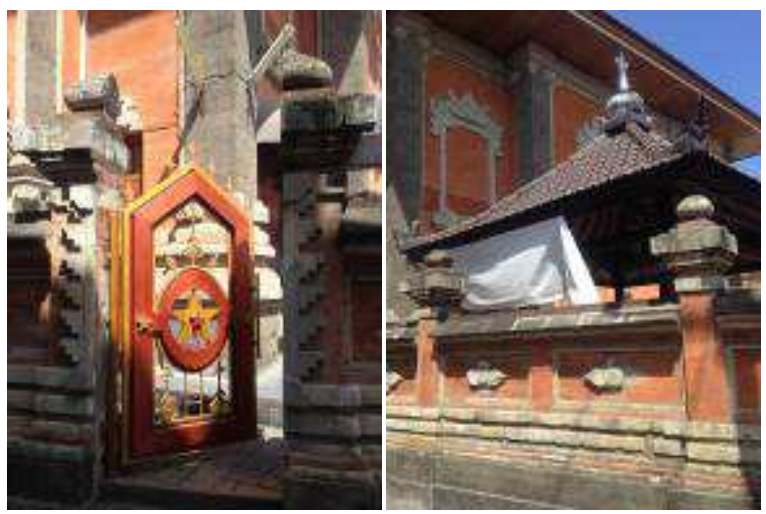

Figure 7. Fence of mosque which applying the element of Balinese style architecture

(Source: survey, 2013)

Applying an element of Balinese style architecture undergone several modification to show the identity as a worship place of Moslems. First, stylization the kekarangan ornament which animal ornament so it does not look real form because of the prohibition in Islam to applying ornament formed living beings like animal or human. Second, used of dome ornament on the top of the roof is intended to building function as a mosque is easily recognizable by Moslems.

\section{Sudirman Grand Mosque, Denpasar City.}

From the beginning of constructing until before renovation at 1994, Sudirman Grand Mosque have joglo formed with closed wall. Used joglo form because the majority of Moslems in around of mosque are migrants from Java so it has proximity with joglo as well as to bring they sense close to home.

Renovation at 1994, Sudirman Grand Mosque change by applying a Balinese wantilan form. Used a that form because an awareness of congregation to appreciate Balinese style architecture with the intention to show they existence as Moslems who respect local values.

Applying wantilan building form in Sudirman Grand Mosque because of philosophical aspect as a gathering place where the wantilan building in Hindu tradition serves as a gathering space together in social and religious activities while the mosque is a space for Moslems gather together in various aspects of they life.
Sudirman Grand Mosque building not have the leg part, and only have a body and head part of the building that make it different from the typical Balinese wantilan form. Body part of building is an open space with no walls and column with canggahwang element to confirm characteristic of wantilan Bali. The building mosque is dominated by white color and without ornament that are meant to show the impression a clean and sacred as a worship place of Moslems as well as to distinguish it from wantilan building owned by Hindus.

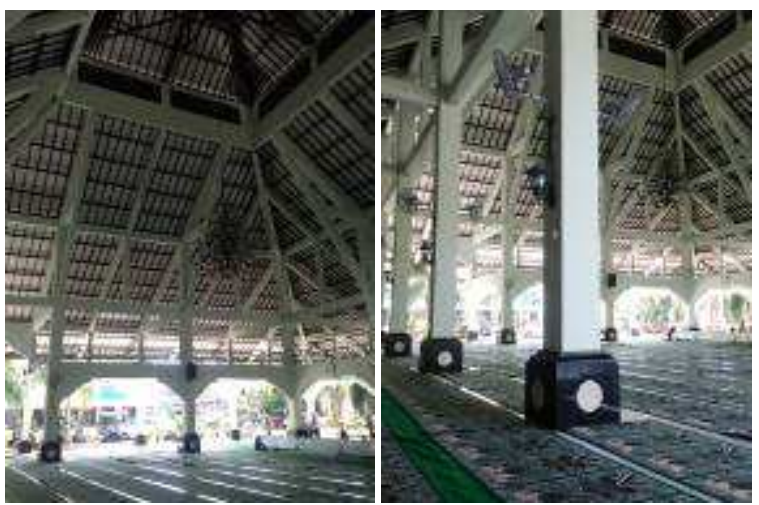

Figure 8. Body part of Sudirman Grand Mosque building (Source: survey, 2013)

The head part of mosque building applying a two level storey pyramid roof to confirm characteristic Balinese wantilan building. Roof covered by roof tile with ikut celedu ornament in each edge of the ridge which is a typical ornament of Balinese style architecture. To show identity as a mosque to be easily recognized by Moslems, especially for Moslem traveler, on the top of the roof using ornament of lafadz Allah.

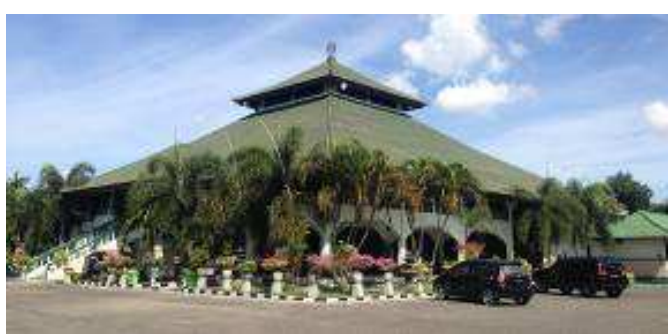

Figure 9. Perspective view of Sudirman Grand Mosque (Source: survey, 2013)

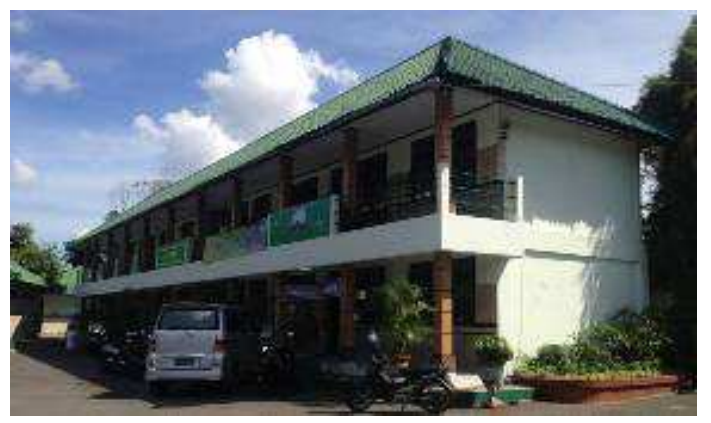

Figure 10. Supporting building of mosque (Source: survey, 2013) 
Adaptation strategy are pursued through architecturally by applying Balinese wantilan building form, also applying non-architectural adaptation strategy is to give access for non-Moslems to use the supporting building is located in the area of Sudirman Grand Mosque. That is an effort to familiarize the social relation between Moslems and other believer so that the existence of Sudirman Grand Mosque be widely accepted by the public.

\section{Nurul Huda Mosque, Badung Regency.}

At the beginning of construction, Nurul Huda Mosque have a simple building form with a pyramid roof and dome ornament on the top of roof. Renovation at 2003, overall building form change by applying architectural styles of Middle East mosque over several consideration. First, architecture of the Middle East-style mosque is a ideal mosque by the congregation and easily recognized especially for Moslem traveler, considering Nurul Huda Mosque in the area of Ngurah Rai Airport. Secondly, the architecture of the Middle East-style mosque by the ta'mir of mosque have the impression of vast and open space so provide convenience for the congregation.

The body part of main building that function as main prayer hall is an open space while building mass on the left and the right side is a massive enclosed space because that function as an office. The curves were used as a structural ornament also function to confirm characteristic of Middle Eaststyle mosque.

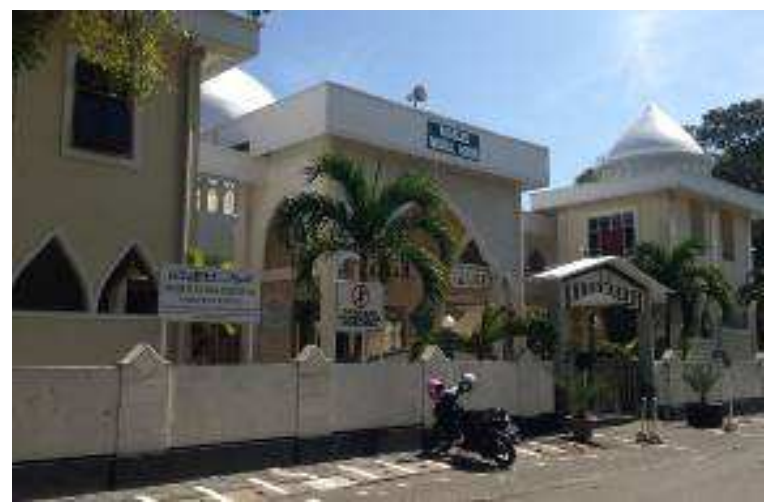

Figure 11. Perspective view of Nurul Huda Mosque (Source: survey, 2013)

From the color aspect, Nurul Huda Mosque dominated apply beige color which is meant to give the impression of cool and calm relating to the function of mosque as a worship place that can give peace and inner coolness for congregation.

The head part of Nurul Huda Mosque building applying a flat roof combined with a dome roof. Largest dome roof covered prayer room located in the central part of the mosque building, while the small-sized dome roof covered office building mass in the right and left side of main building.
Nurul Huda Mosque which appyling architectural styles of Middle East mosques in the minority neighborhood encourage the ta'mir of mosque and congregation perform adaptation strategy in architectural and non-architectural aspect to prevent horizontal conflict between religious communities. The first strategy is to put an office building that seemed massive form at the left and right of the main mosque building and raising a fence that the Moslems worship does not interfere the absorption of Hindus and Christians worship.

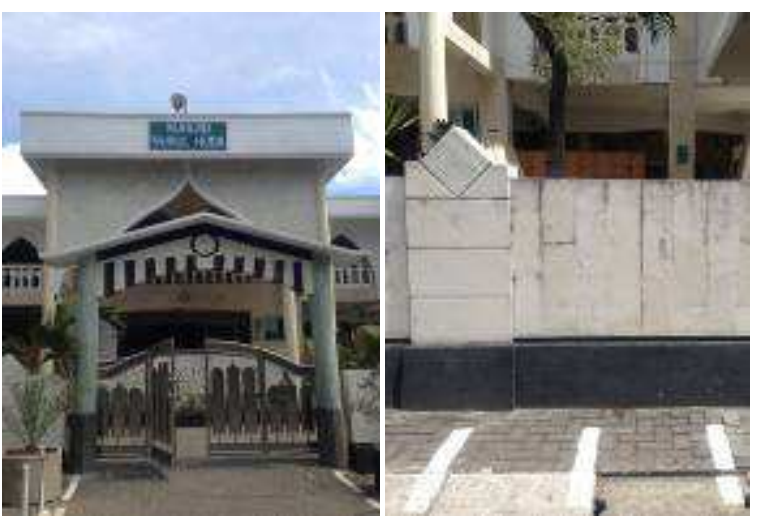

Figure 12. Gate and fence of Nurul Huda Mosque (Source: survey, 2013)

Before renovation at 2003, fence of Nurul Huda Mosque resemble with the church fence which open form so that when Moslems worship in a mosque can be seen by Hindus and Christians from the outside of the mosque which cause discomfort for Moslems themselves and for Hindus and Christians who see it. Learning from that experience, then the renovation at 2003 aim to change the fence mosque into massive and high fence.

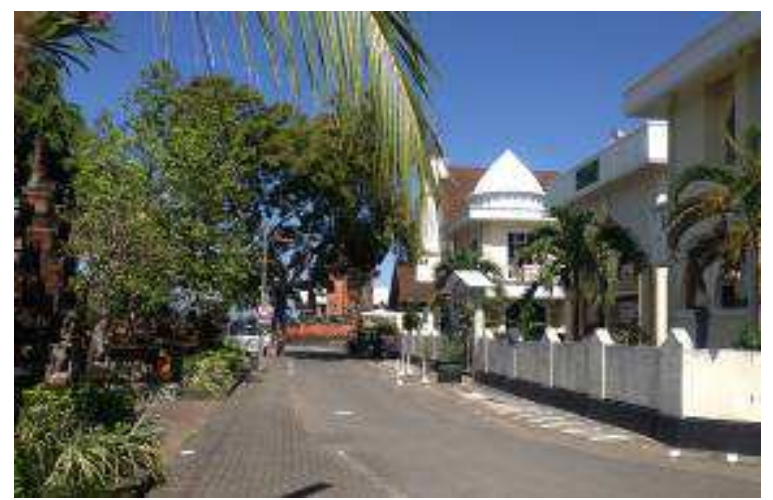

Figure 13. Nurul Huda Mosque located near with temple and church building

(Source: survey, 2013)

The second strategy is carried out by the ta'mir of mosque and the congregation of Nurul Huda Mosque is also active in helping secure the event of Hindus and Christians worship. That strategy was pursued into the social consciousness of all religious communities in around of Nurul Huda Mosque 
neighborhood horizontally to avoid conflict caused by misunderstanding and jealousy between believer.

\section{Asasuttaqwa Mosque, Badung Regency.}

At the beginning of construction, building form of Asasuttaqwa Mosque is very simple which use clay wall with an area $12 \mathrm{~m}^{2}$. Renovation at 1960 replacement building wall with brick, and renovation at 1965 expand the mosque building for the first time with similiar building form since the beginning of construction. It was at 1990 the overall renovation of the mosque building form so that it have present form.

The ta'mir of mosque was inspired by the Istiqlal Mosque in Jakarta, which is considered to represent an ideal form of mosque in Indonesia, which reflect the grandeur and monumental form so that the ta'mir of mosque decided to applying architectural styles of Middle East mosque, especially the position of Asasuttaqwa Mosque in the side of Ngurah Rai Street is the entrance to the Ngurah Rai airport, to be easily recognizable from distance by traveler Moslems.

The body part of mosque building consists of two storey building which is dominated white color for show purity and cleanliness value as a worship place of Moslems. The body of mosque building is covered by a door and a window with a widely transparent glass because mosque located in side of main road which congested by vehicles to keep dust and dirt from the street does not enter into the prayer room and can give the impression of openness of space through the transparent glass are used. And used of arch element are intended to confirm the architectural styles of Middle East mosques that applied.

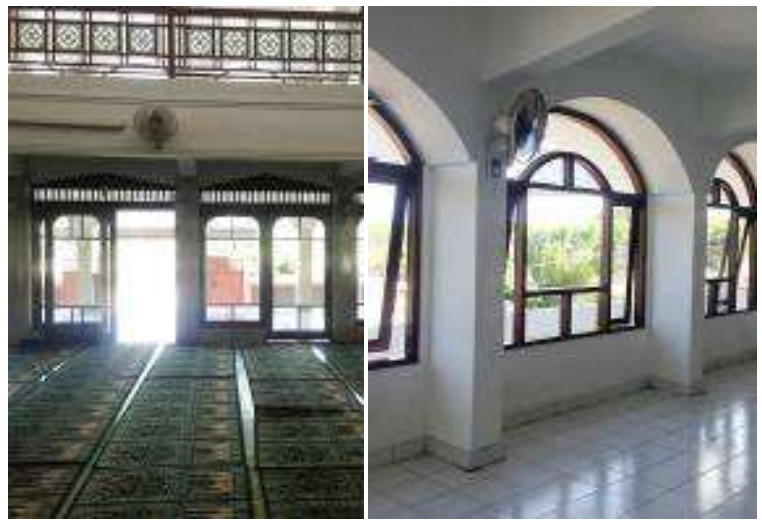

Figure 14. Body part of Asasuttaqwa Mosque (Source: survey, 2013)

The head part of mosque building applying a dome roof which covered prayer hall. Used a roof dome is meant to be able to present a vast prayer hall without column, to give the impression of the grandeur of the worship place of Moslems, and to confirm the characteristic mosque architecture of
Middle East, so that building function as a mosque is easily recognizable by Moslems and people of other faiths.

On one side of mosque building there is a minaret, as well as two smaller minaret on the roof which is intended to give monumental impression that can be recognized the building function as a mosque from the distance. Especially in the minority neighborhood where very limited number of mosques, minaret can be viewed by the people from distance considered necessary to facilitate Moslems to find Asasuttaqwa Mosque.

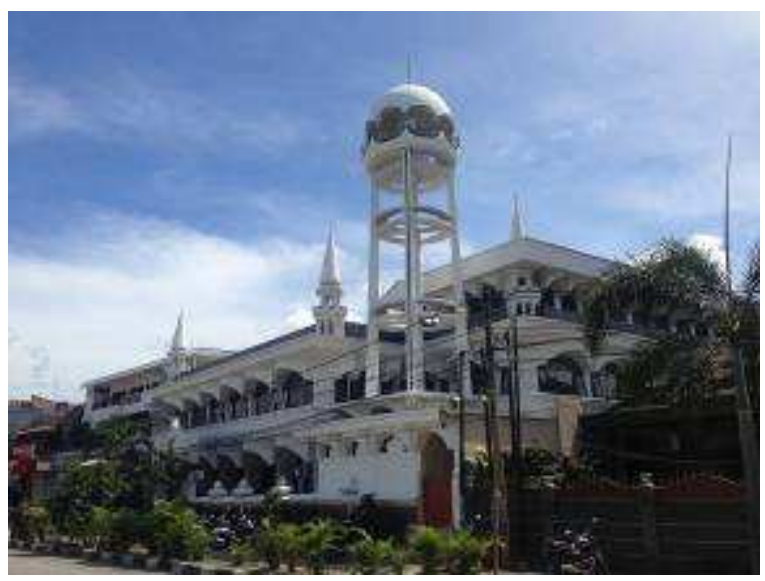

Figure 15. Minaret in one side of Asasuttaqwa Mosque (Source: survey, 2013)

At early 2000, the ta'mir of Asasuttaqwa Mosque encouraged by the local government to applying element of Balinese style architecture to preserving the local architectural tradition. On the one hand, the ta'mir and the congregation of Asasuttaqwa Mosque want to keep the building form is considered ideal mosque to represents a worship place of Moslems, but on the other hand there are demand from the government to applying the element of Balinese architecture.

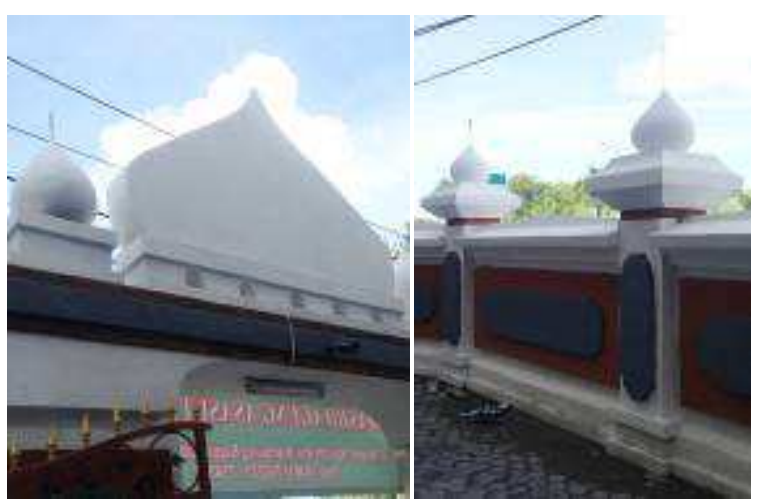

Figure 16. Gate and fence of Asasuttaqwa Mosque (Source: survey, 2013)

Efforts to applying characteristic Balinese style architecture can be seen in the fence form is used a paduraksa on each side. On the fence body used brick and sandstone material, as well as pepalihan 
ornament intended to confirm the characteristic of Balinese style architecture.

Applying local architectural element that is used does not literaly, but the modification efforts through fusion with Middle Eastern architectural element at the head part of gate which used dome element. That is intended to keep the characteristic of mosque which is idealized by the ta'mir and the congregation of Asasuttaqwa Mosque.

Elements of Balinese style architecture is applied only in the fence which is an element of separation between mosque with the outside environment. This show that local Moslems in the muamalah life willing to applying element of local culture which does not contradict with Islam that aims to maintain harmony with other believer, but in the aspect of worship they are not willing to applying the element which not part of Islamic culture that idealized.

\section{Discussion}

The fourth object of study are al-Qomar Mosque, Sudirman Grand Mosque, Nurul Huda Mosque, and Asasuttaqwa Mosque, that have different adaptation strategies related with its presence in the minority neighborhood, which can chategorized into three types:

The first type is implemented by the al-Qomar Mosque. Adaptation is done because of external factor are demand from the government to obey the regulation about Balinese style architecture. That condition on the one hand lead to the rejection by congregation as Balinese style architecture does not reflect the ideal form of mosque, but on the other hand there is a willing to keep the existence of mosque to be accepted by local government and local people from other faiths.

Demand from external and willing to keep the existence of mosque responded by applying dominantly an element of Balinese style architecture in the mosque building with some modification to fit the values of Islam as stylization of ornament formed and used a dome ornament at the top of the main building roof to reflect the mosque identity so that building function is easily recognized by Moslems.

The second type is implemented by the Sudirman Grand Mosque. Adaptation is done because of the internal factor is self-consciousness of the Moslems to applying element of Balinese style architecture with the aim to show they existence as Moslems who appreciate the values of local wisdom.

Internal factor as a driving factor of the adaptation strategy does not make Islamic identity espoused forgotten where the applying a Balinese style element adapted with the values of Islam such as the chosen wantilan form because have similiar philosophy with mosque function as a gathering place for Moslems.
Applying element of Balinese style architecture is not done literaly, but through the efforts of a modification to distinguish element of Balinese style used by Hindus, such as applying wantilan building without leg part and dominated white color without ornament to give the impression a sacred and clean as workship place of Moslem and applying two storey level roof of wantilan building but at the top of the roof there is a lafadz Allah ornament to show the identity of building as a mosque.

The third type is implemented by Nurul Huda Mosque and Asasuttaqwa Mosque. Adaptation is done by showing the characteristic mosque architecture is considered ideal by the congregation in an effort to show the identity of Moslem in the minority neighborhood that is easily recognizable for its existence and to show identity of Moslems who do not want to compromise the worship issue.

Applying a Middle East-style mosque architecture in the minority neighborhood, on the other hand raise fear of jealousy by other believer who can encourage horizontal inter-religious conflict. This is responded by Moslems through openness in muamalah life through mutual aid such as helping secure worship of other believer and social events such as wedding and death ceremony.

The demand from external factor to apply the element of Balinese style architecture do in a small scale in the supporting element of the mosque building such as a fence. That show Moslems want to retain a characteristic mosque architecture is considered ideal to represent identity as Moslems, and show that Moslems in the aspect of worship is not willing to applying the element that originated from the outside of Islamic culture.

Three types of adaptation strategies of mosque architecture that apply by object of study show two things. First, the living condition of Moslems in the Denpasar city and Badung regency is not homogeneous, so it has a wide variety and different adaptation strategies for the existence of a mosque in the minority neighborhood can be accepted by the local government and the wider society.

Second, different neighborhood background between Denpasar city and Badung regency led to the diversity of challenges that must be faced by the Moslems in Denpasar city which is more stringent to apply a local culture value so that external factor be the main factor that led to adaptation strategy of mosque architecture, either awareness to appreciate the local wisdom value or consideration to retain the existence of mosque. While in Badung more 'loose' to apply the local culture value as a major tourist destination with a more heterogeneous cultural background so that Moslems can show the characteristic mosque architecture is considered ideal to represent Moslem identity. 


\section{Conclusion}

Mosque architecture adaptation strategy undertaken by Moslems in Denpasar city and Badung regency vary different based on neighborhood background and identity of Moslems in that neighborhood.

Living in minorities neighborhood encourage Moslems to perform a variety adaptation strategy, both architectural and non-architectural aspect, to retain the existence of mosque in that neighborhood to be accepted by society with different faith. Applying a local architectural element based on the consideration of Islamic value indicate stability retain identity as a Moslems.

Noted that there are three types of adaptation strategt undertaken of Moslems are (1) the demands of external factor are responded by applying dominate Balinese architecture element, (2) awareness to applying a Balinese architecture element to show identity as a Moslems who appreciate local value, and (3) internal factor to applying the characteristic architectural style of the Middle East mosque is considered ideal to represent identity as Moslems.

This preliminary study can be concluded that adaptation strategy of mosque architecture in the minority neighborhood are not homogeneous and is not a one-off work because of adaptation strategy will continue to be done in line with the challenges faced by Moslems.
This also show the persistence of Moslems in Denpasar city and Badung regency to retain the existence of mosque because of the large role of mosque which is the only gathering place for Moslems in the minority neighborhood as well as their symbolic function as a signifier of the presence of Moslem community.

\section{References}

[1] B. P. S. P. Bali, Bali dalam Angka 2010. Denpasar: BPS Provinsi Bali, 2010.

[2] K. Wanili, Ensiklopedia Masjid: Hukum, Adab, dan Bid'ahnya. Jakarta: Darus Sunnah, 2008.

[3] H. Y. Husain, Fikih Masjid. Jakarta: AlKautsar, 2011.

[4] A. Fikriarini, "Masjid: Bentuk Manifestasi Seni dan Budaya," El-Harakah, vol. 11, no. 1, pp. 1-16, 2009.

[5] H. Basyar, "Identitas Minoritas di Indonesia: Kasus Muslim Bali," 2010.

[6] M. S. Barliana, Tipologi Arsitektur Masjid Tradisionalitas Dan Modernitas. Bandung: Metatekstur, 2010. 